Bangladesh J. Agril. Res. 33(3) : 449-457, September 2008

\title{
STUDIES ON THE EFFECTS OF BRADYRHIZOBIUM INOCULATION ON YIELD AND YIELD ATTRIBUTES OF MUNGBEAN
}

\author{
M.A.H. BHUIYAN ${ }^{1}$, M.H. MIAN ${ }^{2}$ AND M.S. ISLAM ${ }^{3}$
}

\begin{abstract}
Field studies with and without Bradyrhizobium was carried out with five mungbean varieties to observe the yield and yield attributes of mungbean. Five mungbean varieties viz. BARI Mung-2, BARI Mung-4, BARI Mung-5, BINA mung-2 and Barisal local, and the rhizobial inoculum (Bradyrhizobium strain BAUR-604) were used. The seeds and stover were dried and weighed adjusting at $14 \%$ moisture content and yields were converted to t/ha. The yield attributing data were recorded from 10 randomly selected plants. BARI Mung-2 produced the highest seed yield (1.03 t/ha in 2001 and $0.78 \mathrm{t} /$ ha in 2002) and stover yield (2.24 t/ha in 2001 and 2.01 t/ha in 2002). Higher number of pods/plant was also recorded in BARI Mung-2, while BARI Mung-5 produced the highest 1000seed weight. Application of Bradyrhizobium inoculant produced significant effect on seed and stover yields in both trials conducted in two consecutive years. Seed inoculation significantly increased seed (0.98 t/ha in 2001, 27\% increase over control and 0.75 t/ha in 2002, 29\% increase over control) and stover (2.31 t/ha in 2001 and $2.04 \mathrm{t} / \mathrm{ha}$ in 2002) yields of mungbean. Bradyrhizobium inoculation also significantly increased pods/plant, seeds/pod and 1000-seed weight. Inoculated BARI Mung-2 produced the highest seed and stover yields as well as yield attributes, such as pods/plant and seeds/pod.
\end{abstract}

Key Words: Bradyrhizobium, inoculation, yield, yield attributes, mungbean.

\section{Introduction}

Mungbean (Vigna radiata L. Wilczek) is one of the most important conventional pulses grown in Bangladesh. It plays an important role in improving the soil fertility by fixing atmospheric nitrogen into available form with the help of rhizobial species present in the nodules of its roots and also important in human diet. However, under agro-ecological conditions of Bangladesh, the nodulation of mungbean is poor, which is one of the major causes of its low yield. Rhizohium inoculation in mungbean increases number of pods and seed yield (Ashraf et al., 2003; Bhuiyan, 2004). Thakur and Panwar (1995) and Solaiman (1999) found an increase in seed yield of mungbean with Rhizobium seed inoculation. There is common notion that legume crop does not need nitrogenous fertilization for their

${ }^{1}$ Senior Scientific Officer, Soil Microbiology Laboratory, BARI, Gazipur-1701, ${ }^{2}$ ViceChancellor, Bangladesh Agricultural University, Mymensingh, ${ }^{3}$ Former Director General, BARI, Gazipur-1701, Bangladesh. 
proper growth. However, Singh et al. (1993) reported that grain yield of mungbean was increased by the application of $20 \mathrm{~kg} \mathrm{~N}$ and $40 \mathrm{~kg}_{2} \mathrm{O}_{5}$, whereas $\mathrm{K}$ application had no significant effect. Therefore, the present study was conducted to determine the effect of seed inoculation with Bradyrhizobium on mungbean and to select a suitable variety on the basis of dry matter production, seed yield and yield attributes for inclusion into cereal based (wheat-rice-rice) cropping pattern during kharif-I season in agroecological zone 9 of Bangladesh.

\section{Materials and Method}

The investigations to determine the effect of seed inoculation with Bradyrhizohium on the production efficiency of different mungbean vrieties were carried out at the Bangladesh Agricultural University Farm, Mymensingh. A field experiment was laid out in randomized complete block design in four replications with a net plot size measuring $4 \mathrm{~m} \times 5 \mathrm{~m}$ on a soil containing $0.10 \% \mathrm{~N}, 10.0 \mu \mathrm{g} \mathrm{g}^{-1}$ available phosphorus, $0.12 \mathrm{meq} 100 \mathrm{~g}^{-1}$ exchangeable potash, $14.0 \mu \mathrm{g} \mathrm{g}$ available sulphur, $1.37 \mu \mathrm{g} \mathrm{g}^{-1}$ available zinc and $0.23 \mu \mathrm{g} \mathrm{g}^{-1}$ available boron in 2001 and $0.10 \% \mathrm{~N}, 9.7 \mu \mathrm{g} \mathrm{g}{ }^{-1}$ available phosphorus, 0.13 meq $100 \mathrm{~g}^{-1}$ exchangeable potash, $13.0 \mu \mathrm{g}$ available sulphur, $1.45 \mu \mathrm{g} \mathrm{g}^{-1}$ available zinc and $0.20 \mathrm{\mu g} \mathrm{g}^{-1}$ available boron in 2002 .

The experiment comprised of seed inoculation with Bradyrhizobium and control (without seed inoculation). Five mungbean varieties viz. BARI Mung-2, BARI Mung-4, BARI Mung-5, BINA Mung-2 and Barisal local were planted using a seed rate of $35 \mathrm{~kg} / \mathrm{ha}$ in 30 apart rows. All the fertilizers were broadcast at sowing in the form of triple superphosphate, muriate of potash, gypsum, zinc sulphate, and boric acid. Rhizobium strain BAUR 604 (Rhizobium spp.) was obtained from Dept. of Soil Science, Bangladesh Agricultural University, Mymensingh and peat based inoculant was used in this experiment. Viability count of bradyrhizobia in the inoculant was made one day before injecting the peat following plate count method (Vincent, 1970). The average number of bradyrhizobia was approximately above $10^{8}$ cells $\mathrm{g}^{-1}$ in the inoculant. The mungbean seeds were coated with gum acacia. After that, inoculum was mixed with gum acacia coated mungbean seeds and the seeds were shade dried.

Ten plants were selected randomly at maturity from each plot for recording pods/plant, seeds/pod and 1000-seed weight, whereas yield was recorded on net plot basis. The data collected were analyzed by using analysis of variance techniques and Duncan's New Multiple Range Test was applied to test the significance of treatment means. 


\section{Results and Discussion \\ Seed yield}

The different varieties of mungbean varied significantly in terms of seed yield (Table 1). The highest seed yield was recorded in BARI Mung-2 that was statistically similar to BARI Mung 5. BARI Mung-2 produced higher dry weight, root nodules and pods/plant, which resulted in higher seed yield. BARI Mung-5 recorded the second highest seed yield, which was followed by BARI Mung-4, BINA Mung-2 and Barisal local. Barisal local gave the minimum yield. The present result is in agreement with Samanta et al. (1999) who reported that varieties of mungbean differed significantly in seed yield. In modern varieties, the reasons for obtaining high seed yield might be due to high dry matter accumulation, high number of pods/plant and 1000-seed weight as compared to local variety. The high seed yield of mungbean in 2001 compared to that in 2002 season might be due to early sowing and higher ambient temperature prevailing during the growth period and more rainfall in 2001 (Figs. 1 and 2). Mungbean being a warm season plant produces higher yield in the optimum mean temperature range from 28 to $30^{\circ} \mathrm{C}$ (Paehlman, 1991 Samanta et al., 1999).

Seed inoculation with Bradyrhizobium significantly increased the seed yield of mungbean in both the years (Table 2). The increase in yield due to Bradyrhizobium inoculation compared to uninoculated control was $27 \%$ and $29 \%$ in 2001 and 2002, respectively. The increase in yield in inoculated treatment might be attributed to increased nodules/plant and nodule dry weight, resulting in higher dry-matter accumulation during the growth period and translocation of more photosynthate to the seed (Rani and Kodandaramaiah, 1997). Ashraf et al. (2003) showed that seed inoculation with Bradyrhizobium strain significantly increased mungbean seed yield.

Table 1. Yield of five varieties of mungbean during kharif-I, 2001 and 2002.

\begin{tabular}{|c|c|c|c|c|c|}
\hline \multirow{2}{*}{\multicolumn{2}{|c|}{ Variety }} & Stover yield (t/ ha) & & Seed yield (t/ha) & \\
\hline & & 2001 & 2002 & 2001 & 2002 \\
\hline BARI & Mung-2 & $1.03 a$ & $0.78 a$ & $2.24 \mathrm{a}$ & $2.0 \mathrm{Ia}$ \\
\hline BARI & Mung-4 & $0.86 \mathrm{bc}$ & $0.68 \mathrm{bc}$ & $2.15 a b$ & $1.90 a b$ \\
\hline BARI & Mung-5 & $0.95 \mathrm{ab}$ & $0.74 \mathrm{ab}$ & $2.20 \mathrm{a}$ & I .94ab \\
\hline BINA & Mung-2 & $0.83 c$ & $0.62 c$ & $2.00 b c$ & $1.77 \mathrm{bc}$ \\
\hline \multicolumn{2}{|c|}{ Barisal Local } & $0.69 \mathrm{~d}$ & $0.50 \mathrm{~d}$ & $1.97 \mathrm{c}$ & $1.69 \mathrm{c}$ \\
\hline \multicolumn{2}{|l|}{$\mathrm{SE}( \pm)$} & 0.029 & 0.021 & 0.050 & 0.046 \\
\hline \multicolumn{2}{|l|}{ Sig. } & $*$ & $*$ & $*$ & $*$ \\
\hline
\end{tabular}

In a column, the figure(s) having same letter are not significantly different

* Significant at $5 \%$ level 


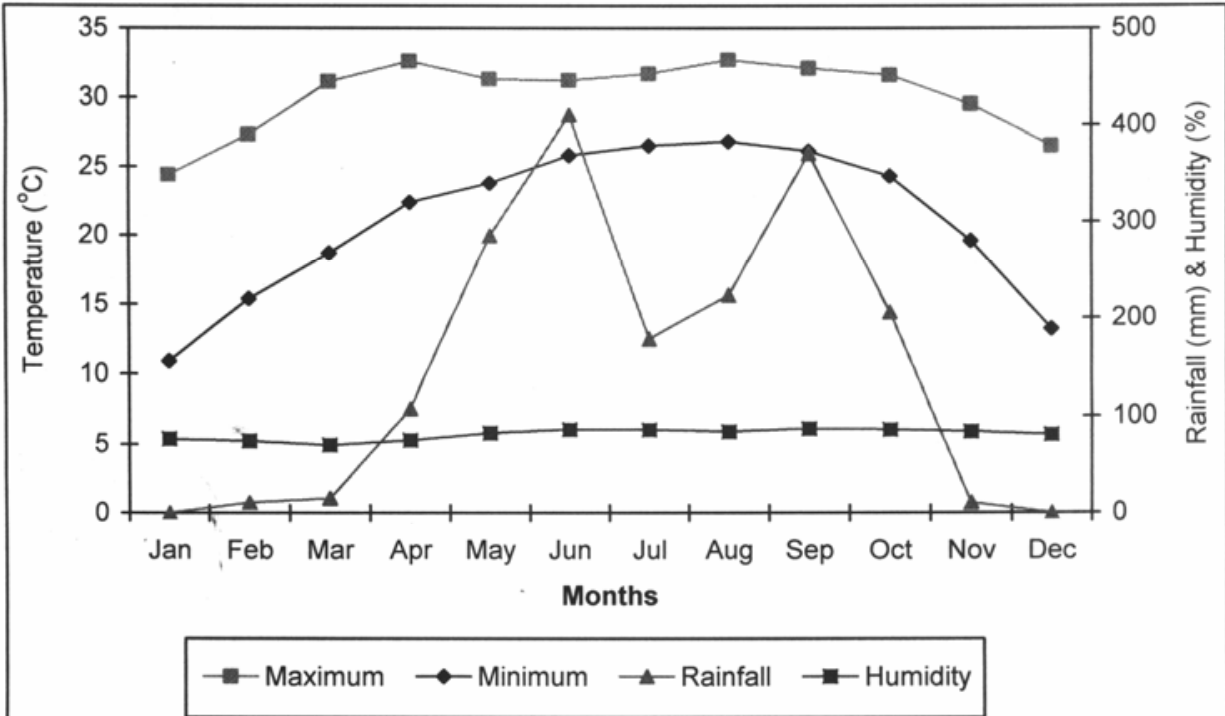

Fig. 1. Monthly temperature, rainfall and relative humidity during 2001

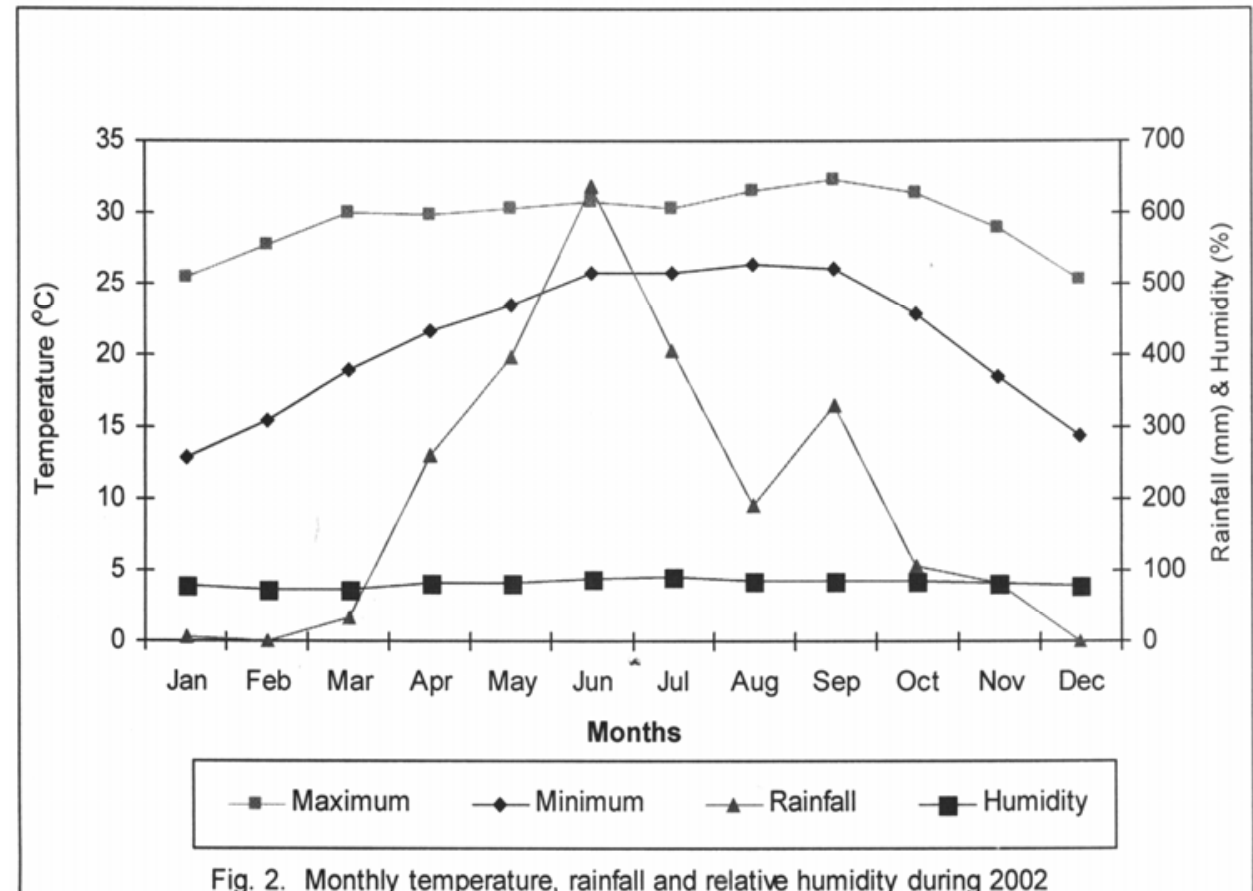

The interaction effects of different varieties of mungbean and Bradyrhizobium inoculant were not significant in terms of seed yield (Tab1e 3). In both the years, BARI Mung-2 gave high yield compared to other varieties both 
under inoculated and uninoculated conditions. Among the mungbean varieties, Barisal local gave the lowest seed yield.

Table 2. Effects of bradyrhizobial inoculant on yield of mungbean during kharif-I, 2001 and 2002.

\begin{tabular}{|c|c|c|c|c|}
\hline \multirow[t]{2}{*}{ Inoculant } & Seed yield (t/ha) & & Stover yield (t/ha) & \\
\hline & 2001 & 2002 & 2001 & 2002 \\
\hline $\begin{array}{l}\text { Uninoculated } \\
\text { Inoculated }\end{array}$ & $\begin{array}{l}0.77 b \\
0.98 a\end{array}$ & $\begin{array}{l}0.58 \mathrm{~b} \\
0.75 \mathrm{a}\end{array}$ & $\begin{array}{l}1.92 \mathrm{~b} \\
2.31 \mathrm{a}\end{array}$ & $\begin{array}{l}\text { L68b } \\
2.04 a\end{array}$ \\
\hline $\mathrm{SE}( \pm)$ & 0.018 & 0.014 & 0.032 & 0.029 \\
\hline Sig. & $*$ & * & $*$ & * \\
\hline
\end{tabular}

In a column, the figure(s) having different letter(s) differed significantly

* Significant at $5 \%$ level

Table 3. Interaction effects of different varieties and inoculant on yield of mungbean during kharif-I, 2001 and 2002.

\begin{tabular}{|c|c|c|c|c|c|c|c|c|}
\hline \multirow{2}{*}{ Treatment } & \multicolumn{4}{|c|}{ Seed yield (t/ha) } & \multicolumn{4}{|c|}{ Stover yield (t/ha) } \\
\hline & $\mathrm{U}$ & I & $\mathrm{U}$ & $\mathrm{I}$ & $\mathrm{U}$ & I & $\mathrm{U}$ & $\mathrm{I}$ \\
\hline BARI Mung-2 & 0.92 & 1.14 & 0.65 & 0.90 & 2.00 & 2.48 & 1.81 & 2.20 \\
\hline BARI Mung-4 & 0.76 & 0.96 & 0.60 & 0.76 & 1.96 & 2.34 & 1.72 & 2.08 \\
\hline BARI Mung-5 & 0.79 & 1.11 & 0.64 & 0.85 & 1.97 & 2.43 & 1.73 & 2.15 \\
\hline BINA Mung-2 & 0.75 & 0.91 & 0.56 & 0.67 & 1.85 & 2.15 & 1.60 & 1.93 \\
\hline Barisal Local & 0.61 & 0.77 & 0.44 & 0.56 & 1.80 & 2.14 & 1.52 & 1.85 \\
\hline $\mathrm{SE}( \pm)$ & \multicolumn{2}{|c|}{ _ } & \multicolumn{2}{|c|}{-} & \multicolumn{2}{|c|}{-} & \multicolumn{2}{|c|}{-} \\
\hline CV (\%) & \multicolumn{2}{|c|}{9.4} & \multicolumn{2}{|c|}{9.1} & \multicolumn{2}{|c|}{6.7} & \multicolumn{2}{|c|}{7.0} \\
\hline
\end{tabular}

U= Without Bradyrhizobium, I= Inoculated with Bradyrhizobium

NS= Not significant

\section{Stover yield}

Results presented in Table I show that BARI Mung-2 produced the highest stover yield, which was statistically similar to that found in BARI Mung-4 and BARI Mung-5, but statistically higher over BINA Mung-2 and Barisal local both in 2001 and 2002 trials. The highest stovcr yield recorded by BARI Mung-2 was attributed to influence higher branches/plant and increased plant height. Barisal local variety gave the lowest stover yield. All the varieties produced higher stover yields in 2001 than in 2002. The higher stover yields in 2001 were found mainly due to early sowing in kharif-I, 2001 compared to kharif-I, 2002. Saini and Jaiswal (1991), and Samanta et al. (1999) reported that temperature had 
tremendous influence on mungbean growth and observed that high temperature favoured vegetative growth and consequently increase in stover yield.

Bradyrhizobium inoculation significantly increased the stover yield over uninoculated one (Table 2). Bradyrhizobium inoculation increased the stover yield by $20 \%$ in 2001 and $21 \%$ in 2002 over uninoculated control. Increased nodulation due to seed inoculation resulting in increase in the vegetative growth, which has increased the seed yield as well as stover yield. The results obtained are in accordance with Shukla and Dixit (1996a). They reported that Rhizohium inoculation increased mungbean seed yield over uninoculated plots. Solaiman (1999) also found significantly higher yield due to application of Rhizobium inoculation which corroborated with present findings.

The stover yields were higher in BARI Mung-2 in both the years (Table 3). The maximum stover yield was obtained from BARI Mung-2 with Bradyrhizobium inoculation, which was higher over any other interaction treatments. This was probably due to better utilization of Bradyrhizohium with BARI Mung-2. The lowest stover yield was with uninoculated Barisal local.

Table 4. Yield attributes of five varieties of mungbean during kharif-I, 2001 and 2002.

\begin{tabular}{|c|c|c|c|c|c|c|}
\hline \multirow{2}{*}{ Variety } & \multicolumn{2}{|c|}{ Pods/plant } & \multicolumn{2}{|c|}{ Seeds/pod } & \multicolumn{2}{|c|}{ 100-seed weight (g) } \\
\hline & 2001 & 2002 & 2001 & 2002 & 2002 & 2002 \\
\hline BARI Mung-2 & 23.9a & 23.Oa & $10.48 a$ & $10.36 a$ & $30.3 b$ & 30.1h \\
\hline BARI Mung-4 & 23.3ab & 22.3ab & $10.46 a$ & $10.30 \mathrm{a}$ & 29.1b & $30.2 b$ \\
\hline BARI Mung-5 & $19.4 \mathrm{c}$ & $18.3 c$ & 9.64ab & $9.45 \mathrm{ab}$ & 38.Oa & 38.Ia \\
\hline BINA Mung-2 & 23.0ab & 21.9ab & $10.55 a$ & 10.39a & $26.3 c$ & 26.2hc \\
\hline Barisal Local & $20.7 \mathrm{bc}$ & 19.9bc & 9.30b & $9.05 b$ & 22.ld & $23.2 c$ \\
\hline $\mathrm{SE}( \pm)$ & 0.93 & 0.57 & 0.30 & 0.32 & 0.78 & 0.94 \\
\hline Sig. & * & $*$ & $*$ & $*$ & $*$ & $*$ \\
\hline
\end{tabular}

In a column, the figure(s) having same letter are not significantly different

* Significant at $5 \%$ level, NS= Not significant

\section{Pods/plant}

Variety x inoculation interaction effect on pod production was not significant, but the varietal and Bradyrhizobium inoculant effects were highly significant (Table 4-6). The pods/plant (mean of inoculated and uninoculated treatment) was the highest in BARI Mung-2 and the lowest in BARI Mung-5 both in 2001 and 2002 (Table 4). Pod production in BARI Mung-4 and BINA Mung-2 was similar to that of BARI Mung-2. 
Bradyrhizobium inoculation significantly increased the number of pods/plant (Table 5). Inoculated plants (average of all varieties) produced 6 pods more than the uninoculated plants. Similar response of the mungbean varieties may be attributed to their parental similarities and similarities in genotypic make-up.

Table 5. Effects of Bradyrhizobial inoculant on yield attributes of mungbean during kharif-I, 2001 and 2002.

\begin{tabular}{|c|c|c|c|c|c|c|}
\hline \multirow{2}{*}{ Inoculant } & \multicolumn{2}{|c|}{ Pods/plant } & \multicolumn{2}{|c|}{ Seeds/pod } & \multicolumn{2}{|c|}{ 100-seed weight (g) } \\
\hline & 2001 & 2002 & 2001 & 2002 & 2002 & 2002 \\
\hline Uninoculated & 19.lb & 18.41, & $9.64 b$ & $9.48 b$ & $27.5 b$ & $28.3 b$ \\
\hline Inoculated & $25.0 \mathrm{a}$ & $23.7 \mathrm{a}$ & $10.54 a$ & $10.35 a$ & $30.8 \mathrm{a}$ & $30.8 \mathrm{a}$ \\
\hline $\mathrm{SE}( \pm)$ & 0.59 & 0.36 & 0.19 & 0.20 & 0.49 & 0.60 \\
\hline Sig. & * & $*$ & $*$ & $*$ & $*$ & $*$ \\
\hline
\end{tabular}

In a column, the figure(s) having different letter(s) differed significantly

* Significant at $5 \%$ level

\section{Seeds/pod}

The effect of variety and inoculation on seeds/pod was significant but their interaction effect was not significant (Table 4-6). The number of seeds/pod differed significantly among the varieties (Table 4). BINA Mung-2 produced the highest number of seeds/pod, which was statistically similar to all other varieties except Barisal local. Bradyrhizobium inoculation significantly increased number of seeds/pod (Table 5). Similar results were obtained by Patel and Patel (1991) and Shukia and Dixit (1996b). But these results were not similar to that of Mozumder (1998) and Naher (2000), who reported that Bradyrhizobium inoculation did not significantly increase the number of mature seeds/pod. Variety x Bradyrhizobium interaction effect on the number of seeds/pod was not statistically significant (Table 6). Higher number of seeds/pod was observed in inoculated BARI Mung-2.

\section{0-seed weight}

The mean effects of Bradyrhizobium and variety on 1000-seed weight were significant, but their interaction effect was not significant (Table 4-6). Maximum weight of 1000-seed was obtained in BARI Mung-5 (average of inoculum). Bradyrhizobium inoculation significantly increased the 1000 -seed weight over no inoculation (Table 5). Results showed that 1000-seed weight (mean over variety) was higher in inoculated plants over uninoculated plants. This result was similar to that of Shukla and Dixit (1996a; 1996b); Provorov et al. (1998) and Naher 
(2000). The interaction effect of variety x Bradyrhizobium inoculation was not significant in respect of 1000-seed weight (Table 6). This might be due to the similar response of different varieties to Bradyrhizobium. Thousand-seed weight was highest in inoculated BARI Mung-5 and it was the lowest in uninoculated Barisal local.

Table 6. Interaction effects of different varieties and inoculant on yield attributes of mungbean during kharif-I, 2001 and 2002.

\begin{tabular}{|c|c|c|c|c|c|c|}
\hline \multirow{2}{*}{ Treatment } & \multicolumn{2}{|c|}{ Pods/plant } & \multicolumn{2}{|c|}{ Seeds/pod } & \multicolumn{2}{|c|}{ 100-seed wet (g) } \\
\hline & $\mathrm{U}$ & I & $\mathrm{U}$ & I & $\mathrm{U}$ & I \\
\hline \multicolumn{7}{|l|}{ Kharif-1, 2001} \\
\hline BARI mung-2 & 20.5 & 27.3 & 9.75 & 11.20 & 28.8 & 31.8 \\
\hline BARI mung-4 & 21.5 & 25.0 & 10.18 & 10.75 & 27.5 & 30.8 \\
\hline BARI mung-5 & 16.7 & 22.0 & 9.27 & 10.00 & 35.6 & 40.4 \\
\hline BINA mung-2 & 19.7 & 26.8 & 10.15 & 10.95 & 25.3 & 27.3 \\
\hline Barisal Local & 17.2 & 24.2 & 8.82 & 9.78 & 20.2 & 24.0 \\
\hline $\mathrm{SE}( \pm)$ & & - & & - & & - \\
\hline Sig. & & ns & & is & & ns \\
\hline \multicolumn{7}{|l|}{ Kharif-1, 2002} \\
\hline BARI mung-2 & 19.8 & 26.1 & 9.70 & 11.03 & 28.6 & 31.7 \\
\hline BARI mung-4 & 20.6 & 24.0 & 10.10 & 10.50 & 29.7 & 30.7 \\
\hline BARI mung-5 & 16.0 & 20.5 & 9.00 & 9.90 & 35.5 & 40.7 \\
\hline BINA mung-2 & 18.7 & 25.0 & 9.98 & 10.80 & 25.2 & 27.3 \\
\hline Barisal Local & 16.7 & 23.0 & 8.60 & 9.50 & 22.7 & 23.7 \\
\hline $\mathrm{SE}( \pm)$ & - & - & - & - & - & - \\
\hline Sig. & & & & & & NS \\
\hline cv (\%) & 7.7 & & & .1 & & 9.0 \\
\hline
\end{tabular}

U=Without Bradyrhizobium, 1= Inoculated with Bradyrhizobium NS $=$ Not significant

From two years' study, it was observed that the seed yield of the tested mungbean ranged between 0.5 and $1.0 \mathrm{t} / \mathrm{ha}$, which was quite reasonable yield in the tropical climate while the stover yield ranged from 1.69 to $2.31 \mathrm{t} / \mathrm{ha}$. The effect of inoculation on the seed and stover yields was also observed. Bradyrhizobium inoculation significantly increased seed and stover yield of mungbean. But varietal response to inoculation was insignificant. BARI Mung-2 had the highest yield. The variety BARI Mung-2 may be recommended for cultivation with or without Bradyrhizobium inoculation. 


\section{References}

Ashraf, M., M. Mueen-Ud-Din and N. H. Warraich. 2003. Production efficiency of mungbean (Vigna radiata L.) as affected by seed inoculation and NPK application. Inter. J. Agric. Biol. 5 (2): 179-180.

Bhuiyan, M. A. H. 2004. Evaluation of introducing mungbean into cereal based cropping pattern for sustainable soil fertility and productivity. Ph. D. Thesis, Dept of Soil Sci., Bangladesh Agril. Univ., Mymensingh, Bangladesh. pp. 1-2 17.

Mozumder, S. N. 1998. Effect of nitrogen and rhizobial fertilizer on two varieties of summer mungbean (Vigna radiata L. Wilczek). M.S. Thesis, Dept of Agron., Bangladesh Agril. Univ., Mymensingh, Bangladesh. pp. 1-76.

Naher, S. 2000. Comparative performance of bio-fertilizer and chemical fertilizer on the yield and yield contributing characters of mungbean. M.S. Thesis, Dept of Agron., Bangladesh Agril. Univ., Mymensingh, Bangladesh. pp. 1-62.

Paehlman, J. M. 1991. The mungbean. 1st edn. Oxford and IBH Publishing Co. Pvt. Ltd., New Delhi, Bombay and Calcutta, pp. 27-29.

Patel, F. M. and L. R. Patel. 1991. Response of greengram varieties to phosphorus and Rhizobium inoculation. Indian J. Agron. 36 (2): 295-297.

Provorov, N. A., U. B. Saimnazarov, I. U. Bahromoy, D. Z. Pulatova, A. P. Kozhemyakov and G. A. Kurbanov. 1998. Effect of rhizobia! inoculation on the seed (herbage) production of mungbean (Phaseolus aureus Roxb.) grown at Uzbekistan. J. Arid Envir. 39 (4): 569-575.

Rani, B. P. and D. Kodandaramaiah. 1997. Response of soybean (Glycine max) to inoculation with varying nitrogen levels. Indian J. Agron. 42(1): 135-137.

Saini, S. S. and V. P. Jaiswal. 1991. Response of summer greengram (Phaseolus radiatus) to date of planting. Indian J. Agron. 36 (3): 427-428.

Samanta, S. C., M. H. Rashid, P. Biswas and M. A. Hasan. 1999. Performance of five cultivars of mungbean under different dates of sowing. Bangladesh .1. Agril. Res. 24 (3): 521-527.

Shukia, S. K. and R. S. Dixit. 1996a. Nutrient and plant population management in summer greengram (Phaseolus radiatus). Indian J. Agron. 4 1(1): 78-83.

Shukia, S. K. and R. S. Dixit. 1996b. Effect of Rhizobium inoculation, plant population and phosphorus on growth and yield of summer greengram (Phaseolus radiatus). Indian .J. Agron. 41 (4): 611-615.

Singh, A. K., R. K. Choudhary and R. P. R. Sharma. 1993. Effect of inoculation and fertilizer levels in yield, yield attributes and nutrient uptake of greengram (Phaseolus radiatus) and blackgram (P. mungo). Indian J. Agron. 38 (4): 663-665.

Solaiman, A. R. M. 1999. Response of mungbean to Bradyrhizobium sp. (Vigna) inoculation with and without phosphorus and potassium fertilization. Bangladesh $J$. Sci. Res. 17 (2): 125-132.

Thakur, A. K. and J. D. 5. Panwar. 1995. Effect of Rhizobium VAM intercactions on growth and yield of mungbean (Vigna radiala L.) under field conditions. Indian $J$. Plant Path. 38: 62-65. 
Vincent, J. M. 1970. Selective Indicator Media. A Manual for the practical study of the root nodule bacteria. IBP Hand Book No. 15: 4. 